\title{
Taxonomic Studies on Skulls of European bison and Domestic Cattle Hybrids
}

\author{
Franciszek KOBRYŃCZUK \& Małgorzata KRASIŃSKA
}

\begin{abstract}
Kobryńczuk F. \& Krasińska M., 1987: Taxonomic studies on skulls of European bison and domestic cattle hybrids. Acta theriol., 32, 12: 203-218 [With 2 Tables \& 5 Figs.].

Using three indices for five skull measurements, discriminant functions were calculated to allocate skulls of the European bison and domestic cattle. These functions were then applied to skulls of hybrids between bison and cattle. The results of this analysis were used to estimate the degree of relationship of hybrids with parental forms. It has been found that the skulls of $F_{1}$ hybrids are more similar to the skulls of domestic cattle than bison. In backcross generations $\mathrm{B}_{1}, \mathrm{~B}_{2}$, and $\mathrm{B}_{3}$ with decreasing proportions of the bison blood $(25-12.5-6.25 \%)$, the similarity to the skulls of domestic cattle increased. Hybrids are characterized by highly differential skull shapes. The skulls of male hybrids show a variable degree of similarity to the skulls of domestic bulls, but are not exactly alike to them. The skulls of female hybrids, however, are more similar to the skulls of either bison or cattle, or they are indentical with the skulls of domestic cows. The pattern of inheritance of quantitative traits of $\mathrm{F}_{1}$-hybrid skulls is complicated by heterosis. Bison from the Pszczyna line have skulls of different shape than bison from the Białowieża line, which may be due to a high degree of inbreeding in this line.

[Dept. of Animal Anatomy, Warsaw Agricultural University, Nowoursynowska 166, 02-766 Warszawa, Poland, and Mammals Research Institute, Polish Academy of Sciences, 17-230 Białowieża, Poland]
\end{abstract}

\section{INTRODUCTION}

The similarity of hybrids of the European bison and domestic cattle to the original parental forms was analysed by many authors (Dehnel, 1960; Demiaszkiewicz, 1961; Krasińska, 1963, 1967, 1971a, 1979a). As the number of hybrids increased, it was also possible to study the postnatal morphology and development of these animals (Krasińska, 1969, 1971b, $1979 \mathrm{~b})$. The collected skeletons of hybrids provide opportunity for osteological studies. Another paper on this subject deals with craniometric characteristics of hybrids (Krasińska, in press). It contains a detailed description of similarities and differences between skulls of hybrids and their parents. 
The aim of this paper is to analyse relationships between skull characteristic in hybrids and the degree of their relationship to the European bison and domestic cattle.

To characterize the variables, Fisher's (1936) discriminant functions and Wrocław taxonomy (Florek et al., 1951) were used.

\section{MATERIAL AND METHODS}

The material consisted of skulls of a pure form of lowland European bison, Bison bonasus bonasus (Linnaeus, 1758), domestic cattle, Bos taurus Linnaeus, 1758, and hybrids of these species, including $F_{1}$ generation and backcross generations $\mathrm{B}_{1}, \mathrm{~B}_{2}, \mathrm{~B}_{3}$, in which the proportion of bison blood formed a decreasing geometric series: $25,12.5$, and $6.25 \%$.

The European bison skulls, $47(23,24)$ in number, derived from animals bred in enclosures, including $23(13,10)$ from the lowland Białowieża line and $24(10,14)$ from the lowland Pszczyna line. The names of the Białowieża bison start with "Po", and the names of Pszczyna bison start with "PI" or "Ka" (Table 1). The age of bison taken from the Pedigree Boak of the European Bison (Źabinski, 1947-65; Zabiński \& Raczyński, 1972). The skulls of the domestic cattle of the red Polish breed $(r p)$ and black-white lowland breed $(b w l), 24(4,20)$ in number, were roughly aged as "young" or "old' on the basis of ossification of neurocranial sutures (Table 1). The skulls of hybrids derived from 53 specimens (24, 29) of known age. As their lineages were known, it was possible to calculate their relationship with bison $(R)$ using the formula:

$$
R_{o a}=\sum\left(\frac{1}{2}\right)^{n}
$$

where $R$ is the relationship coefficient (percentage of blood) with bison, and $n$ is the number of sections on the line from a forbear to/ a progeny. The list of hybrids, their age, and relationship coefficients are given in Table 1 .

The first generation of hybrids $F_{1}$ descended from a male bison and a domestic cow or, conversely, from the cross of a domestic bull and a female bison. Three bison were used for hybridization: male Pokorny (Pedigree no. 1077) and two females: Podkomorzanka (1085) and Ponętna (1073). The domestic cattle used for crossbreeding were represented by the bull Ananas of $r p$ breed, the bull Richtje of bwl breed, and his son born from a domestic cow of bwl breed. The hybrids of backcross generations $B_{1}, B_{2}$, and $B_{3}$ were obtained by the mating of female hybrids of different generations with domestic bulls of bwl breed (Dehnel, 1960; Demiaszkiewicz, 1961; Krasińska, 1963, 1967, 1969, 1971a, 1971b, 1979a, 1979b).

The following measurements of the skull (Fig. 1), as defined by Duerst (1926) were taken:

1. Basal lenght of the skull - Basion-Prosthion (BP)

2. Interorbital breadth - Ectorbitale-Ectorbitale (EctEct)

3. Breadth of the splanchnocranium - Supramolare-Supramolare (SmSm)

4. Height of the splanchnocranium - Staphylion-Nasion (StN)

5. Height of the neurocranium - Sphenobasion-Bregma ( $\mathrm{SphBr}$ ). 

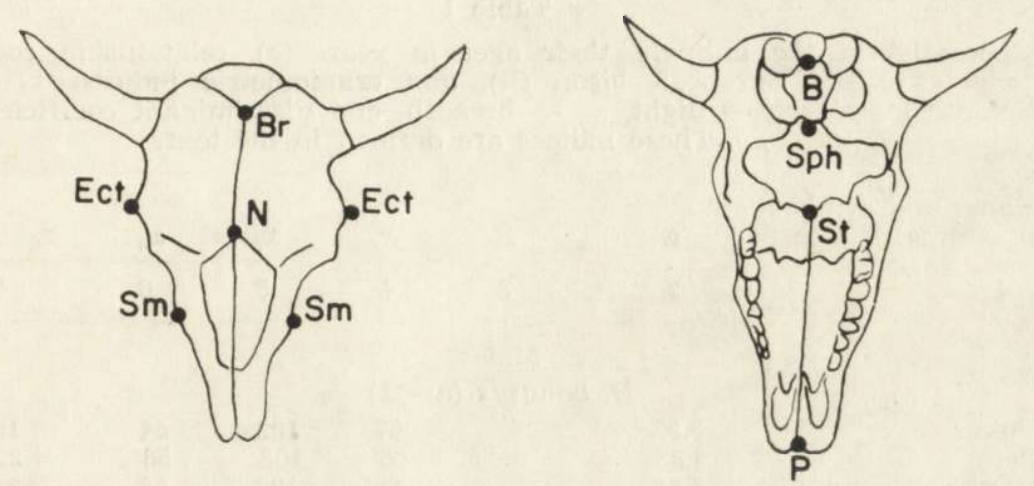

Fig. 1. Measurement points on the skull.

The following craniometric indices were calculated:

$$
x_{1}=\frac{E c t E c t \times 100}{B P}, x_{2}=\frac{S t N \times 100}{S p h B r}, \text { and } x_{3}=\frac{S m S m \times 100}{E c t E c t} .
$$

$x_{1}$ is called the breadth-length index, $x_{2}$ hight index, and $x_{3}$ breadth index.

The values of these indices (Table 1) were used to calculate Fisher's (1936) discriminant function separating bison and cattle skulls of either sex. This function was then used to allocate craniometric indices of hybrids.

Correlations were analysed between discriminant coefficients $(z)$, on the one hand, and the relationship coefficients with bison $(R)$ or age $(a)$, on the other hand. In addition, Wrocław taxonomy (Florek et al., 1951) was used for skull ordination on the basis of craniometric indices (Tables 1 and 2). The least Czekanowski differences were calculated. For this purpose a joint dendrite for bison, cattle, and hybrids of the two sexes was calculated, and an individual dendrite.

The osteological material was taken from the museum collection of the Department of Animal Anatomy of the Agricultural University of Warsaw and from the Mammals Research Institute at Białowieża.

Terminology is based on the Veterinary Anatomic Nomenclature (Pilarski, 1978). The term "cranium" is used in its old meaning, that is, for the facial part (splanchnocranium) and the neural part (neurocranium) as a whole.

\section{RESULTS}

The breadth-length index of the skull $\left(x_{1}\right)$ was the highest for bison of the two sexes, the lowest for domestic cows and hybrid cows, and intermediate for domestic and hybrid bulls. The breadth index $\left(x_{2}\right)$ was also highest for bison, lowest for cattle, and intermediate for hybrids The hight index $\left(x_{3}\right)$, to the contrary, was lowest for bison, highest for cattle, and intermediate for hybrids (Tables 1 and 2). In general it can thus be stated that the skulls of bison, as compared with those of cattle, are shorter and larger, with higher and narrower splanchnocranium and lower neurocranium. 
Table 1

Check-list of the animals, their ages in years $(a)$, relationship coefficients to the European bison $(R)$, and craniometric indices: $x_{1}-$ breadth-length, $x_{2}-$ hight, $x_{3}$ - breadth, and discriminant coefficient $\left(z_{B b-B t}\right)$. These indices are defined in the text.

Name and symbol

\begin{tabular}{ccccccc} 
of animal & $a$ & $R$ & $x_{1}$ & $x_{2}$ & $x_{3}$ & $z_{B b-B t}$ \\
\hline 1 & 2 & 3 & 4 & 5 & 6 & 7 \\
\hline \multicolumn{7}{c}{ Males }
\end{tabular}

Pokaz

Potok

Potomek

Pozew

B. bonasus $(n=23)$

Pocztowy

Poganin

Porubanek

Polamaniec

Postęp

Popas

Ponury

Podbipięta

Planetnik

Pleban

Plotkarz

Plater

Plamiec

Plato

Karpacz

Plawik

Pluvius II

3.92

4.83

5.92

6.67

6.33

7.33

8.17

8.33

9.17

9.83

13.50

15.00

17.67

4.50

4.92

6.58

7.25

14.42

17.33

Plisch

16.92

17.25

18.42

1474

3035

$\mathrm{Zm}$

Richtje

ad

B. taurus $(n=4)$

$\begin{array}{llll}67 & 102 & 54 & +19.8\end{array}$

$\begin{array}{llll}66 & 108 & 58 & +22.9\end{array}$

$\begin{array}{llll}65 & 109 & 58 & +23.6\end{array}$

$+23.4$

$+27.6$

$+24.9$

$+25.3$

$+25.2$

$+21.8$

$+25.1$

$+23.8$

$+28.4$

$+33.6$

$+17.5$

$+17.0$

$+22.1$

$+20.9$

$+27.4$

$+30.3$

$+24.2$

$+21.6$

$+23.5$

$+24.0$

108
107

$-19.7$

$\begin{array}{llll}52 & 82 & 70 & -19.7 \\ 49 & 76 & 76 & -32.3\end{array}$

$-21.0$

Females

$\begin{array}{lr} & \\ \text { Polga } & 2.58 \\ \text { Ponętna } & 8.50 \\ \text { Pogon } & 10.00 \\ \text { Poziomka } & 11.92 \\ \text { Polatucha } & 13.33 \\ \text { Pobudka } & 15.42 \\ \text { Ponowa } & 15.00 \\ \text { Polanka } & 16.92 \\ \text { Pojata } & 19.83 \\ \text { Podwika } & 2.50 \\ \text { Pleśnianka } & 1.67 \\ \text { Plica } & 2.00 \\ \text { Plinka } & 2.17 \\ \text { Plusia } & 3.33 \\ \text { Plebanka } & 4.58 \\ \text { Plama } & 6.17 \\ \text { Plewa } & 7.10 \\ & \end{array}$

B. bonasus $(n=24)$

58

8.50
0.00

1.92

13.33

15.42

16.92

19.83

22.50

2.17

3.33

4.58
6.17

7.10
59

59

62

60

57

59

61

57
$+9.7$

-9.3
+-11.7

$+11.7$

$+10.4$

$+7.5$

$+11.5$

+7.4
+

$+11.6$

$+10,2$

+3.3
+2.5

$+4.1$

$\begin{array}{r}4.1 \\ +2.6 \\ \hline\end{array}$

+8.7
+

8.0
+5.7

5.0
+5.7 
Table 1 (continued)

\begin{tabular}{lrrrrrrr}
\hline \multicolumn{1}{c}{1} & 2 & 3 & 4 & & 5 & 6 & 7 \\
\hline Plisa & 7.17 & & 59 & & & & \\
Plastik II & 11.33 & & 60 & & 64 & +5.4 \\
Plarka & 12.33 & & 58 & & 60 & 62 & +7.0 \\
Plötze & 15.92 & & 60 & 94 & 63 & +7.3 \\
Plamka II & 15.33 & & 61 & 92 & 61 & +8.4 \\
Planarie & 18.42 & 60 & 92 & 63 & +7.0 \\
Pleinze & 18.25 & 57 & 94 & 66 & +4.2 \\
\hline
\end{tabular}

B. taurus $(n=20)$

\begin{tabular}{|c|c|c|c|c|c|}
\hline & & & & & \\
\hline $\mathrm{Kp}-1$ & ad & 44 & 77 & 78 & -11.4 \\
\hline $\mathrm{Kp}-2$ & ", & 45 & 93 & 77 & -7.8 \\
\hline $\mathrm{Kp}-3$ & & 49 & 85 & 74 & -5.4 \\
\hline $\mathrm{Kp}-4$ & juv & 49 & 84 & 70 & -4.0 \\
\hline $\mathrm{Kp}-6$ & $\mathrm{ad}$ & 45 & 93 & 78 & -8.2 \\
\hline $\mathrm{Kp}-7$ & , & 48 & 81 & 78 & -8.2 \\
\hline $\mathrm{K} p-10$ & ", & 46 & 91 & 82 & -9.4 \\
\hline $\mathrm{Kp}-11$ & & 46 & 80 & 75 & -8.5 \\
\hline $\mathrm{Kp}-12$ & juv & 51 & 87 & 75 & -4.2 \\
\hline $\mathrm{Kp}-14$ & & 55 & 80 & 68 & -1.8 \\
\hline Kp-15 & ad & 46 & 81 & 76 & -8.7 \\
\hline $\mathrm{Kp}-19$ & " & 44 & 87 & 78 & -10.2 \\
\hline Gab. & ", & 45 & 87 & 76 & -8.4 \\
\hline 1468 & ., & 48 & 83 & 73 & -6.0 \\
\hline P-1 & ", & 48 & 85 & 77 & -7.2 \\
\hline $\mathrm{P}-2$ & " & 47 & 88 & 72 & -5.4 \\
\hline P-3 & " & 49 & 78 & 71 & -5.3 \\
\hline P-4 & $"$ & 49 & 88 & 74 & -4.9 \\
\hline P-5 & ", & 47 & 88 & 73 & -5.8 \\
\hline P-6 & ", & 48 & 85 & 71 & -4.7 \\
\hline
\end{tabular}

B. bonasus $\times B$. taurus

Males $(n=24)$

Fakir

Farad

Filip

Facet

Filon

Fest

Felon

Feld

Fellach

Festyn

Feg

Fen

Feb

Fey

Fez

Fetysz

Fenix

Fell

Feston

Fenek

Fenomen

Fen II

Fenol

Feliks

5.25
6.42
8.00
11.33
13.00
0.50
0.50
1.58
2.00
2.00
3.42
3.58
3.58
4.08
4.33
4.42
5.50
7.00
0.42
1.33
4.25
4.33
4.42
2.00

50
50
50
50
50
25
25
25
25
25
25
25
25
25
25
25
25
25
12.5
12.5
12.5
12.5
12.5
6.25

$\begin{array}{ll}52 & 91 \\ 58 & 89 \\ 57 & 90 \\ 60 & 95 \\ 56 & 85 \\ 57 & 92 \\ 58 & 83 \\ 53 & 87 \\ 50 & 94 \\ 56 & 87 \\ 53 & 83 \\ 53 & 88 \\ 52 & 89 \\ 57 & 82 \\ 52 & 89 \\ 54 & 91 \\ 49 & 89 \\ 57 & 86 \\ 60 & 82 \\ 56 & 80 \\ 55 & 89 \\ 53 & 84 \\ 57 & 80 \\ 54 & 83 \\ & \end{array}$

$\begin{array}{lr}68 & -8.2 \\ 66 & -6.9 \\ 61 & -2.1 \\ 67 & -0.5 \\ 62 & -9.0 \\ 71 & -7.9 \\ 65 & -12.7 \\ 68 & -12.3 \\ 71 & -7.9 \\ 66 & -9.7 \\ 68 & -16.8 \\ 75 & -16.8 \\ 61 & -4.8 \\ 68 & -16.5 \\ 66 & -8.8 \\ 72 & -10.8 \\ 71 & -13.7 \\ 67 & -11.3 \\ 63 & -11.6 \\ 68 & -19.4 \\ 73 & -13.4 \\ 67 & -14.8 \\ 68 & -18.7 \\ 72 & -19.5\end{array}$


Table 1 (concluded)

\begin{tabular}{|c|c|c|c|c|c|c|}
\hline 1 & 2 & 3 & 4 & 5 & 6 & 7 \\
\hline \multicolumn{7}{|c|}{ Females $(n=29)$} \\
\hline Filutka & 7.00 & 50 & 50 & 104 & 68 & $+0,6$ \\
\hline Fama & 8.00 & 50 & 51 & 100 & 72 & -1.0 \\
\hline Feeria & 0.50 & 25 & 56 & 86 & 68 & +1.5 \\
\hline Ferina & 0.67 & 25 & 53 & 83 & 74 & -3.6 \\
\hline Felly & 1.25 & 25 & 56 & 74 & 67 & 0.0 \\
\hline Ferma & 1.42 & 25 & 51 & 84 & 73 & -3.9 \\
\hline Fema & 2.33 & 25 & 49 & 83 & 73 & -5.3 \\
\hline Feta & 3.25 & 25 & 47 & 85 & 63 & -2.4 \\
\hline Felpa & 4.42 & 25 & 49 & 92 & 71 & -3.1 \\
\hline Feska & 4.50 & 25 & 49 & 96 & 72 & -2.8 \\
\hline Fewa & 5.50 & 25 & 50 & 84 & 72 & -4.1 \\
\hline Fera & 6.50 & 25 & 46 & 93 & 72 & -5.2 \\
\hline Femina & 7.50 & 25 & 50 & 100 & 71 & -1.2 \\
\hline Fenny & 8.00 & 25 & 50 & 88 & 75 & -4.8 \\
\hline Fena & 0.58 & 12.5 & 47 & 78 & 72 & -7.0 \\
\hline Fetwa & 2.83 & 12.5 & 50 & 84 & 62 & -0.2 \\
\hline Fela & 2.50 & 12.5 & 50 & 84 & 72 & -4.1 \\
\hline Felga & 3.17 & 12.5 & 53 & 81 & 69 & -1.6 \\
\hline Fenicja & 3.42 & 12.5 & 48 & 99 & 71 & -2.6 \\
\hline Fedala & 3.42 & 12.5 & 53 & 89 & 71 & -1.1 \\
\hline Ferajna & 4.17 & 12.5 & 48 & 79 & 64 & -3.1 \\
\hline Fela II & 4.33 & 12.5 & 51 & 90 & 72 & -2.6 \\
\hline Fega & 4.42 & 12.5 & 49 & 86 & 76 & -6.0 \\
\hline Ferara & 4.67 & 12.5 & 47 & 80 & 75 & -7.8 \\
\hline Festa & 5.42 & 12.5 & 49 & 97 & 69 & -1.5 \\
\hline Fedra & 1.00 & 6.25 & 49 & 96 & 72 & -2.8 \\
\hline Felba & 1.00 & 6.25 & 53 & 78 & 72 & -3.2 \\
\hline Ferta & 1.33 & 6.25 & 50 & 86 & 70 & -3.0 \\
\hline Feda & 2.17 & 6.25 & 51 & 89 & 74 & -3.5 \\
\hline
\end{tabular}

Table 2

Mean values of craniometric indices $x_{1}, x_{2}$, and $x_{3}$. (Definitions of these indices are in the text).

\begin{tabular}{lrrrr}
\hline Species, sex & $n$ & $x_{1}$ & $x_{2}$ & $x_{3}$ \\
\hline B. bonasus & & & & \\
Males & 23 & 65.4 & 109.8 & 58.6 \\
Females & 24 & 58.6 & 99.1 & 63.0 \\
B. taurus & & & & \\
Males & 4 & 52.2 & 80.2 & 72.6 \\
Females & 20 & 47.5 & 85.1 & 74.9 \\
B. bonasus $\times$ B & taurus & & & \\
Males & 26 & 55.0 & 86.5 & 68.1 \\
Females & 29 & 50.2 & 87.9 & 70.8 \\
\hline
\end{tabular}

Determinations of the matrix from the sums of variance, covariance, and mean differences of the values of the three indices analyzed for bison bulls $(B b)$ and cattle bulls $(B t)$ yield the following discriminant function:

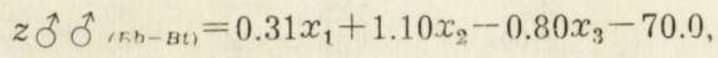


where $z$ is the discriminant coefficient, $x_{1}, x_{2}$, and $x_{3}$ are variables denoting the values of craniometric indices. Analysis of this function indicates that $x_{2}$, which characterizes the ratio of splanchnocranium height to neurocranium height ( $\mathrm{StN}$ and $\mathrm{SphBr}$ ) is of greatest taxonomic power for allocating skulls of males of these two species. The reason is that the coefficient at $x_{2}(1.10)$ is of the highest absolute value, as compared with those at $x_{1}$ and $x_{2}$. The lowest taxonomic power has the index $x_{1}$. Thus, the skulls of domestic bulls as compared with bison bulls are characterized by relatively greater dimension $\mathrm{SphBr}$ and lower $S t N$.

The discriminant coefficients $z$ of all bison bulls are highly positive, whereas those of domestic bulls are negative (Table 1), which means that this function is a good approximation of the data. The difference in the discriminant coefficient $(z)$ between the most "bison-type" skull of Podbipięta and the most "cattle-type" skull of bull 3035 in +33.6$-(-32.3)=65.9^{\circ}$ (see Table 1). In turn, the lowest difference occurs between the discriminant coefficient of bison Pleban and domestic bull Richtje: $+17.0-(-21.0)=38.0$.

There is a significant relationship between the values of $z$ and age (a) of bison bulls $\left(r_{\mathrm{za}}=+0.550, p<0.01\right)$, given by the formula (Fig. 2):

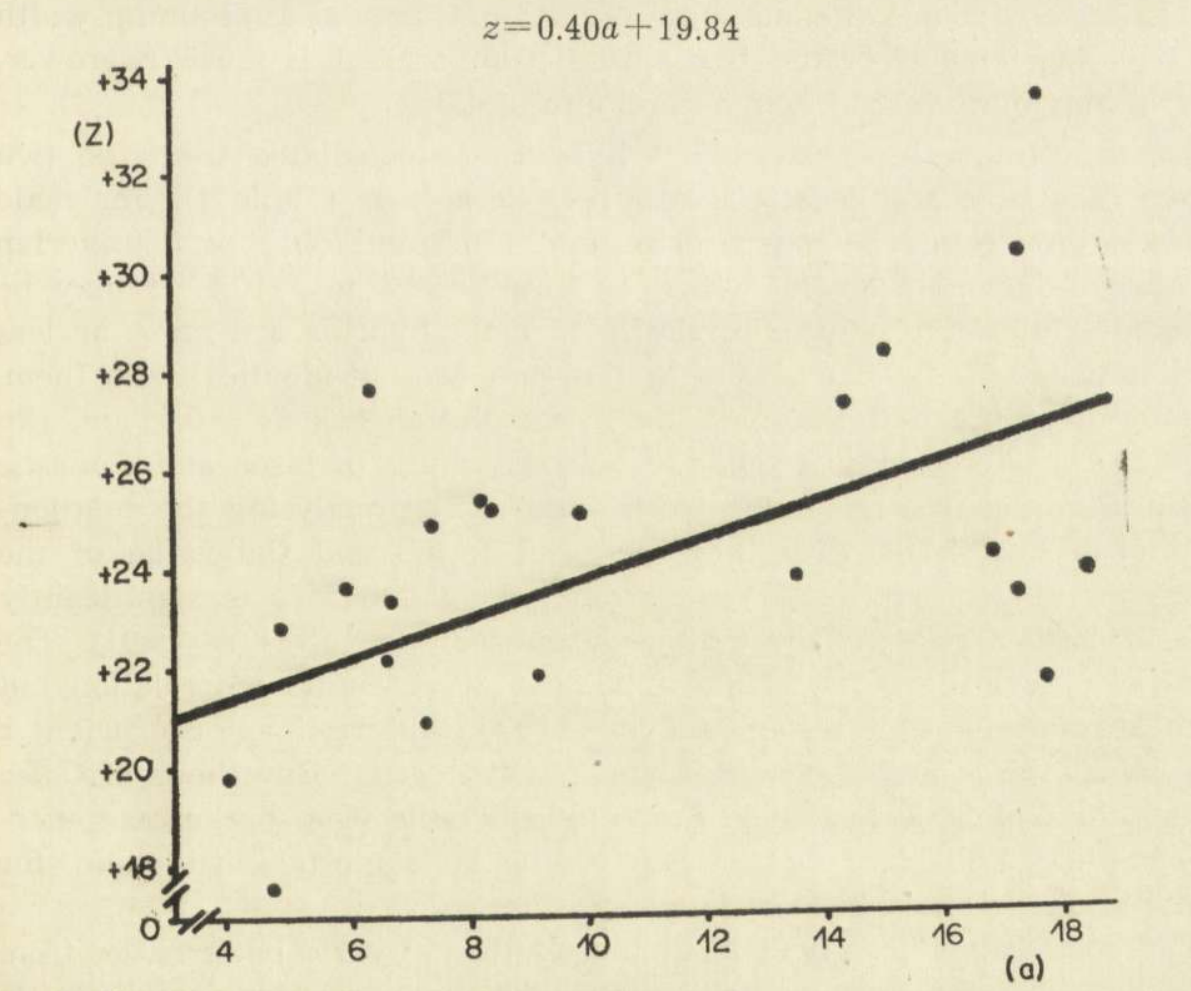

Fig. 2. Correlation of the discriminant coefficient $(z)$ on age $(a)$ in female bison. 
The positive sign of this regression shows that the discriminant ccefficient of bison bulls increases with age, implying that the expression of bison traits in skull increases, A similar process should also be recorded in domestic bulls, but the sample size was too small for such an analysis.

The function allocating skulls of bison cows and domestic cows is of the form:

$$
z_{\rho_{(B b-B t)}}=+0.63 x_{1}+0.16 x_{2}-0.39 x_{3}-21.00,
$$

where $x_{1}, x_{2}$, and $x_{3}$ have the same meaning as in the preceding function. In this case, $x_{1}$, breadth-length index, has the greatest taxonomic power, whereas $x_{2}$ has the lowest power, the reverse of what was found for males. Thus, skulls of female domestic cattle are narrower and longer than skulls of bison cows. The difference in $z$ between the most "bisontype" skull of the cow Poziomka and the most "cattle-type" skull of the domestic cow Kp-1 is $+17.7-(-11.4)=29.1$ (see Table 1). The smallest difference in $z$ was noted for the female pair Plica-Kp-14: $+2.5-(-1.8)=$ $=4.3$.

The difference between sets of discriminant coefficients for bison and cattle can be called an interspecific demarcation zone. As calculated above, for males this zone has a maximum width of 65.9 and a minimum width of 38.0 For females of the two species compared it is much narrower, with a maximum of 23.1 and a minimum of 4.3 .

The discriminant coefficients of hybrids, as calculated from the two above functions, are negative with few exceptions (Table 1). For male hybrids they range between -19.4 and -0.5 and only partly overlap the range for male cattle, which is from -32.3 to -10.4 . It may be concluded, therefore, that the skulls of male hybrids are more or less similar to the skulls of male cattle, but they are not identical with them. The skull of the bull Facet of the $\mathrm{F}_{1}$ generation has $z=-0.5$, and can thus be considered as intermediate between skulls of bison and domestic cattle. Significant correlations were found when analysing the relationship of hybrid bulls with their parental forms and the value of the discriminant coefficient $z$. For example, the value of $z$ is significantly related to the relationship with a bison $(R): r_{\mathrm{zR}}=0.734(p<0.01)$. The regression formula is $z=0.28 R-18.9$ (Fig. 3). A similar correlation but with an opposite sign was noted between the discriminant coefficient $z$ for hybrid bulls and their relationship with cattle. But there are also deviations from this tendency. Some hybrid bulls from backcross generations (Fest, Fellach, Feb) are less similar to domestic cattle than, for example, Fakir or Filon from $\mathrm{F}_{1}$ generation.

The discriminant coefficients of the skulls of hybrid cows range from -7.8 to +1.5 . This range partly overlaps the range for female cattle 
which is -11.4 to -1.8 . The common part of the range of discriminant coefficients is from -7.8 to -1.8 . Consequently, the skulls of female hybrids can be allocated to three groups: 1 . the skulls similar to those of female bison; their coefficients are equal to zero or they are positive (Filutka, Feeria, Felly), 2. the skulls more similar to those of female bison but not identical with them; their coefficients range from -1.8 to zero (Fama, Femina, Fetwa, Felga, Fedala, Festa), and 3. the skulls identical with those of female cattle; their coefficients have a common range from -7.8 to -1.8 (the remaining 20 cows).

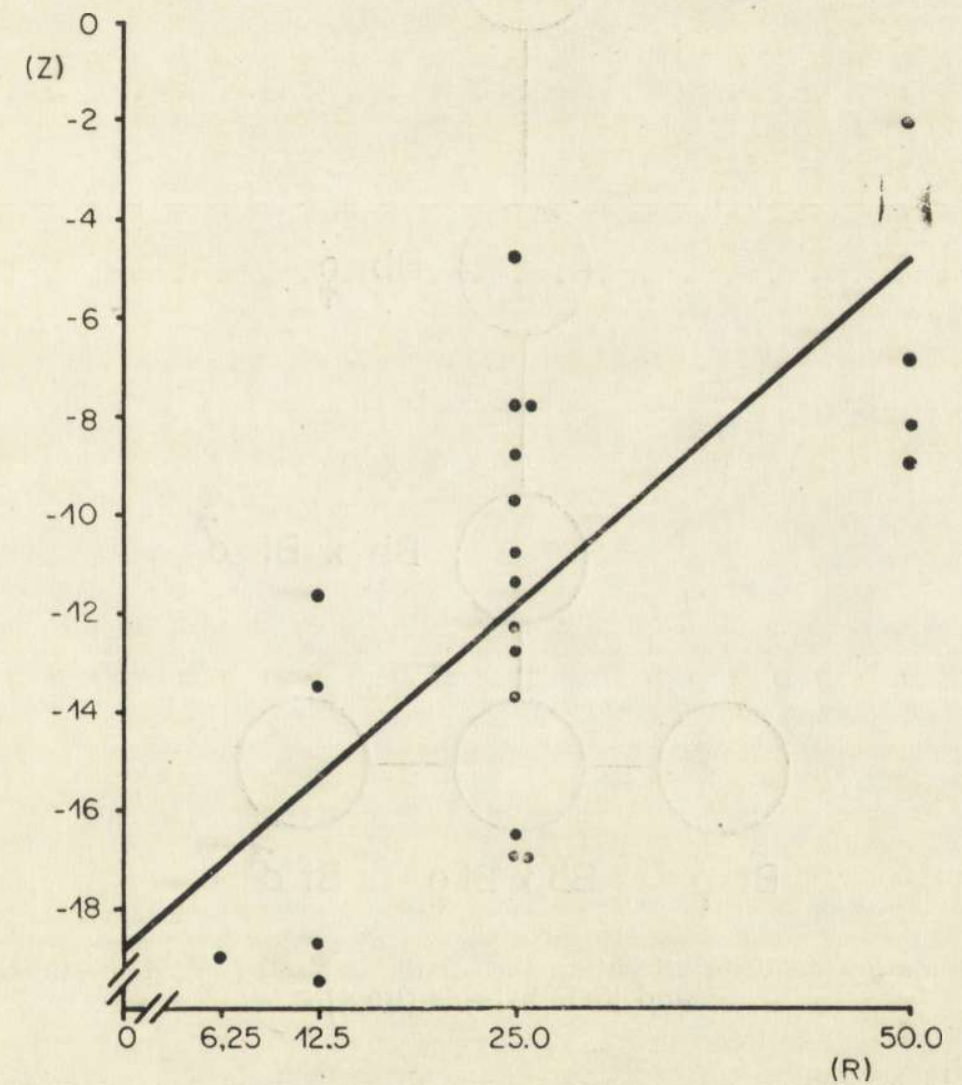

Fig. 3. Correlation of the discriminant coefficient $(z)$ on the relationship coefficient to bison $(R)$ in male hybrids: $B$. bonasus $\times B$. taurus.

The classifying dendrite (Fig. 4), based on the mean values of craniometric indices from table 2, shows that the skulls of hybrid cows are in the centre. The most similar to them are the skulls of hybrid bulls and then the skulls of bulls and cows of domestic cattle. The skulls of bison, especially bulls, are far from this centre. The individual dendrite (Fig. 5) is more detailed. Three groups have been identified in it, A, B, and C. 
Group A, the most uniform, consists of all the bison, excluding Podbipięta, Plato, Pobudka, and also of all Pszczyna bison cows. In its centre there is the female Ponętna - the first mother of some hybrids. This group is joined to group B through two points representing the skulls of Pobudka and Filutka $\left(\mathrm{F}_{1}\right)$, which are thus most similar to each other in terms of the shape of their skulls.

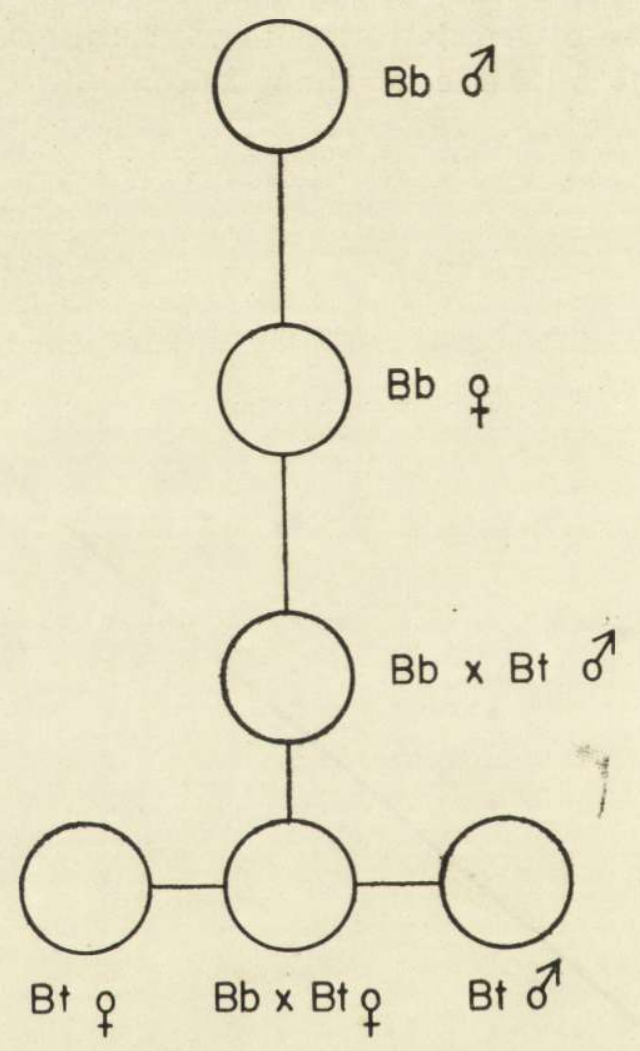

Fig. 4. Summation dendrite allocating the skulls of bison $(B b)$, domestic cattle $(B t)$, and their hybrids $(B b \times B t)$.

Group B, which is less homogeneous with respect to the species composition, mostly consists of skulls of hybrid cows and domestic cows. But the hybrid females Ferina, Felga, Feeria, Felly, Felba, Fena, and Ferajna are absent from this group, and likewise the domestic cows $\mathrm{Kp}-1, \mathrm{P}-3$, and $\mathrm{Kp}-14$. Instead, this group includes the skulls of the hybrid bulls Fen, Fest, Fetysz, and Fenix. This group shows a tendency to polarization. Its lower part mostly concentrates females of domestic cattle, whereas its upper part contains hybrids with skulls similar to bison skulls. The way out from the lower part goes to the domestic bull 
3035, whose skull is most typical of the domestic cattle. The way out from the upper part signifies a higher expression of characters typical of bison skulls, as it is the case of Filutka.

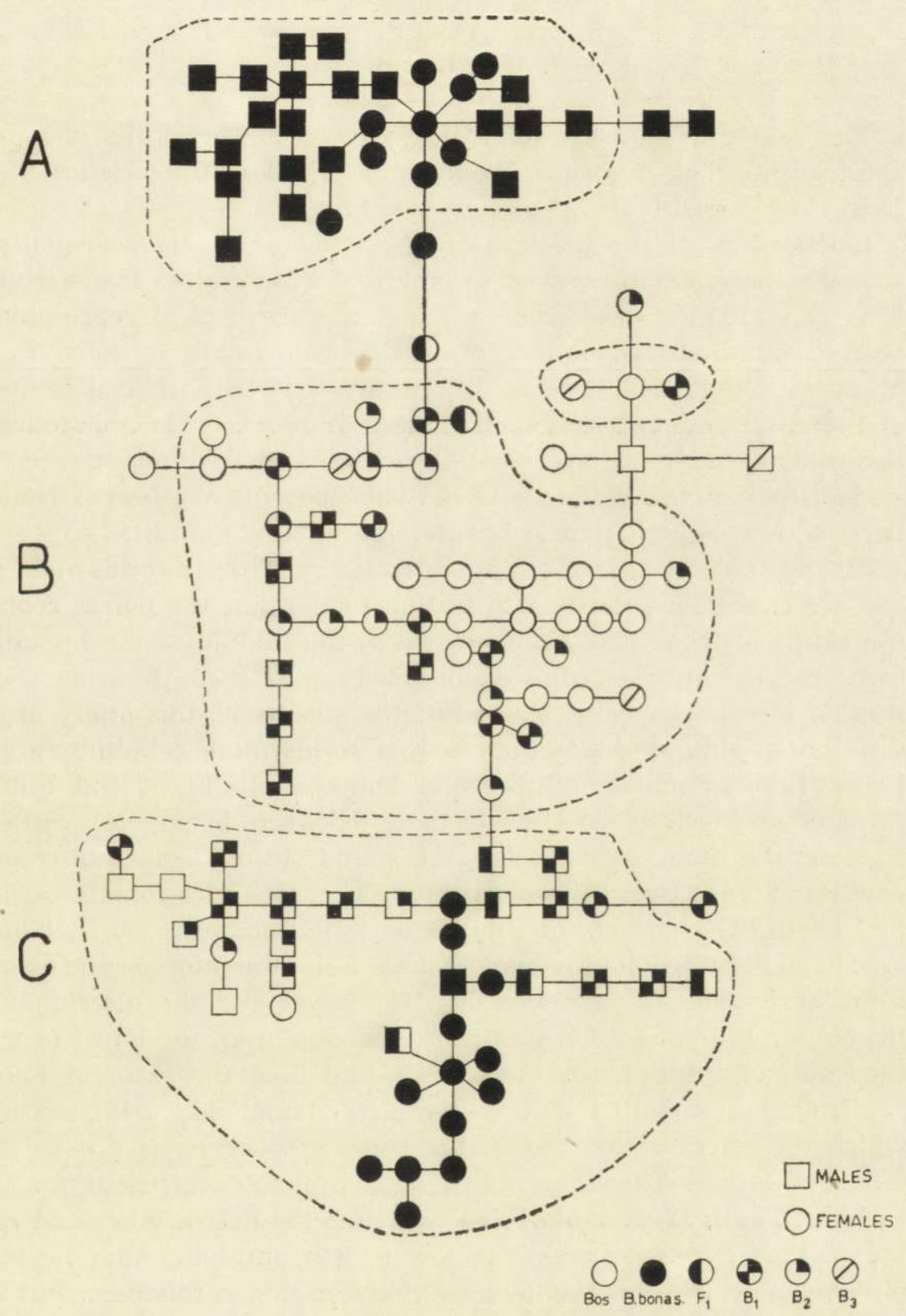

Fig. 5. Dendrite allocating the skulls. 
Group C is even more heterogeneous than group B in terms of the origin of animals. The bulk of this group consists of Pszczyna bison cows, then there are $F_{1}$ hybrid bulls and also scarce representatives of further generations, $B_{1}, B_{2}$, and $B_{3}$, and also the already mentioned bull 3035 .

\section{DISCUSSION}

This paper deals with quantitative traits of the skulls of two related species and their hybrids. Quantitative skull characteristics are among most characteristic of the species, sex, breed.

Independent of the species, an $\mathrm{F}_{1}$ individual should be equally similar to either parent with respect to inherited quantitative traits (Hutt, 1964). This is really the case when the parents are typical representatives of their populations. Deviations from this rule found in some $F_{1}$ hybrids of bison and domestic cattle can imply that both their parents or one of them did not represent their species quite well. The theoretical result, according to Galton's law, should be that each descendant receives more or less half of the gene pool from each parent, one-fourth from grandparents, one-eighth from great grandparents, etc. (Hutt, l.c.).

Fitting the discriminant functions $z_{(B b-B t)}$ to the hybrids of $F_{1}$ generation, we expected, according to Galton's rule, that the points representing the skulls of these animals would be in the middle of the breadth of the demarcation zones, as this would mean that these hybrids were halfsimilar to-each parental form. But the results of this study are a little different (Table 1). Among seven $\mathrm{F}_{1}$ hybrids (males: Fakir, Farad, Filip, Facet, Filon; females: Filutka and Fama), only Facet and Filutka had skull shapes close to intermediate between bison and cattle skulls, whereas the other individuals were similar to cattle in this respect. The parents of Facet were the bison bull Pokorny and a female cattle of the bwl breed. The parents of Filutka were the domestic bull Ananas of $r p$ breed and bison female Podkomorzanka. Since the interspecific demarcation zone for females is narrower than for males and the discriminant coefficient for Filutka $(+0.6)$ was a little higher than for Facet $(-0.5)$, then the skull of Filutka was more bison-like than the skull of Facet. This confirms the so-called maternal effect (Hammond, 1949), according to which the effect of mother on the traits of progeny is greater than the effect of father. The value of the discriminant coefficient for the next $\mathrm{F}_{1}$ hybrid bull, 13-year-old Filon (which is the half-brother of Facet from the mother Podkomorzanka) is low $(-9.0)$, implying that he is similar to domestic cattle. No Hammond's effect occurs in this case. But negative correlation coefficients of the other $F_{1}$ hybrids could have been produced by this effect. Hammond's maternal effect has been found in many 
species of domestic animals (Radomska, 1982), and it has also been analysed in the population of bison and cattle hybrids (Krasińska, 1969). It was found then that this effect was importart in the case of male progeny.

The shape of the skulls of $F_{1}$ hybrids is influenced similar by the original parental forms when they are typical of their respective species. In the case of bison, the material derives from animals kept in enclosures with high inbreeding coefficients (Onopiuk, 1984; Kobryńczuk, 1986), and individuals representing domestic cattle belong to two strains. Thus, both parents can be considered as not typical. The age was not likely to influence the shape of skulls of $F_{1}$ hybrids, as it ranged from 5 to 13 years. At this age, the skull is almost of the final size (Krasinska, 1986) and catabolic processes do not predominate yet.

Heterosis can be the factor shaping skulls of $F_{1}$ hybrids. Heterosis can shift $F_{1}$ hybrids towards the parent showing genetic dominance (Hutt, 1964). This phenomenon is accompanied by a rapid skull growth. The increase in its mass follows the laws of physics. Namely, the transition from small to large constructions requires changes in the proportion of linear dimensions because moments of a force also change as a result of increasing mass.

In backcross generations, the skull shape of hybrid bulls becomes more similar to cattle and less similar to bison. This tendency is shown by a high correlation $\left(r_{2 \mathrm{R}}=+0.696\right)$. But there were no individuals having skulls identical with skulls of domestic cattle, and the demarcation zone between bulls of bison and domestic cattle is wide and impassable for hybrid bulls even from the $\mathrm{B}_{3}$ generation. Thus, the reversion to "cattletype" skulls is rather slow in hybrid bulls and as though delayed when compared with females. Among female backcross hybrids, only few specimens had skulls not identical with the skulls of female cattle. The more rapid reversion to the morphological type of domestic cattle skull in hybrid cows than bulls can be explained by a narrow demarcation zone between female bison and cattle. This tendency to the disappearance of craniometric traits of bison in hybrid skulls does not follow an ordered pattern which could be characterized by a correlation between the affinity with the ancestral forms and the new skull shape, as it is the case for males. There are examples of $F_{1}$ skulls (Fama) with more cattle traits than the skulls of $B_{1}$ generation (Feeria, Table 1). Lack of consistency in this respect may be due to a young age of some females, especially of the $\mathrm{B}_{3}$ generation.

Backcrossing can go in two directions. The crossing of $F_{1}$ hybrids with the parental form which is a dominant homozygote provides the progeny phenotypically similar to this parental form, But if $F_{1}$ is backcrossed 
with the parental form which is a recessive homozygote, half of the progeny will be phenotypically similar to one parent and half to another parent (Hutt, 1964). It is difficult to tell which of these two possibilities took place in the backcrossing of the study hybrids, but rather the first one.

The dendrite taxonomy revealed first of all a great diversity of skull shapes in hybrids of different generations. An indication of this is their presence in groups B and C (Fig. 5). The isolated position of Pszczyna bison cows with resepct to the main bison group (A) indicates that they have specific skull proportions. This is likely to be an effect of their long-term, lasting for over one hundred years, breeding with close relatives and, consequently, of a high degree of inbreeding which could have made their skulls somewhat similar to the skulls of domestic cattle.

\section{REFERENCES}

1. Czekanowski J., 1913: Zarys metod statystycznych w zastosowaniu do antropologii. Pr. TNW: 1-228. Warszawa.

2. Dehnel A., 1960: Beobachtungen über Zusammenleben von Wisent und Hausrind. Acta theriol., 3: 314-317.

3. Demiaszkiewicz W., 1961: Die Geburt eines Hybriden von Bison bonasus (L) $\sigma^{7}$ und Bos taurus dom. L., ㅇ. Acta theriol., 5: 51-56.

4. Duerst J. U., 1926: Vergleichende Untersugungsmethoden am Skelett bei Saügern. Urban und Schwarzenberg, 7: 125-530. Berlin-Vien.

5. Empel W., 1962: Morphologie des Schädels von Bison bonasus (Linnaeus, 1758). Acta theriol., 6: 53-111.

6. Fisher R. A., 1936: The use of multiple measurements in taxonomic problems. Annals Eug., 7: 179-188.

7. Florek K., Łukaszewicz J., Perkal J., Steinhaus H. \& Zarzycki S., 1951: Sur la liaison et la division des points d'un ensemble fini. Colloq. Math., 2: 282-285 . Wrocław.

8. Hammond J., 1949: Zwierzęta gospodarskie. Inst. Wyd. Roln. PWN: 1-340. Warszawa.

9. Hutt F. B., 1964: Animal Genetics. Roland Press Co.: 1-542. New York.

10. Kobryńczuk F., 1986: The influence of inbreeding on the shape and size of the skeleton of the European bison. Acta theriol., 30: 379-422.

11. Krasińska M., 1963: Weitere Untersugengen über Kreuzungen des Wisents, Bison bonasus (Linnaeus, 1758) mit Hausrind, Bos taurus dom. Linnaeus, 1758. Acta theriol., 7: 301-310.

12. Krasińska M., 1967: Crosses of wisent and domestic cattle. V. Acta theriol., 12: $67-80$.

13. Krasińska M., 1969: The postnatal development of $F_{1}$ hybrids of European bison and domestic cattle. Acta theriol., 14: 69-117.

14. Krasińska M., 1971a: Hybrydization of European bison with domestic cattle. Part VI. Acta theriol., 16: 413-422.

15. Krasińska M., 1971b: Postnatal development of $B_{1}$ hybrids of European bison and domestic cattle. Acta theriol., 16: 423-438. 
16. Krasińska M., 1979a: Progress in breeding European bison and domestic cattle hybrids and casuistics in cases of immobilization and pasteurelosis in hybrids. Acta theriol., 24: 201-210.

17. Krasińska M., 1979b: Postnatal development of European bison and domestic cattle hybrids of backcrosses $B_{2}$ and $B_{3}$. Acta theriol., 24: 211-220.

18. Krasińska M., (in press): Variability in the shape of skull of the European bison and domestic cattle hybrids. Acta theriol.

19. Krysiak K., 1983: Anatomia zwierząt. PWN: 1-638. Warszawa.

20. Onopiuk W., 1984: Historia, warunki utrzymania i analiza wplywu inbredu na

- rozród i długość życia żubrów w Białowieży. Master thesis. Szkoła Główna Gospodarstwa Wiejskiego - Akademia Rolnicza: 1-96. Warszawa.

21. Pilarski W., (Ed.) 1978. Weterynaryjne Mianownictwo Anatomiczne. PWN. 1-695. Warszawa.

22. Radomska M. J., 1982: Metody i kierunki doskonalenia zwierząt. PWN: 1-245. Warszawa.

23. Żabiński J., (Ed.) 1947-65: Pedigree book of the European bison. PWN: 1-370. Warszawa.

24. Żabiński J., \& Raczyński J., (Eds) 1972: European bison pedigree book 1965-69. PWN: $1-78$. Warszawa.

Received 12 February 1986, Accepted 7 April 1987.

Franciszek KOBRYÑCZUK i Małgorzata KRASIŃSKA

\section{BADANIA TAKSONOMICZNE CZASZEK HYBRYDOW ŻUBRA I BYDEA DOMOWEGO}

\section{Streszczenie}

Badania przeprowadzono na 47 czaszkach żubrów nizinnych czystej krwi, Bison bonasus bonasus (Linnaeus, 1758), 24 czaszkach bydła domowego, Bos taurus Linnaeus, 1758 i 53 czaszkach hybrydów tych dwóch gatunków. Głównym celem pracy było określenie podobieństwa czaszek hybrydów do wyjściowych form rodzicielskich.

W badaniach zastosowano dyskryminację Fishera (1936) i taksonomię wrocławską (Florek et al., 1951). Na wszystkich czaszkach zmierzono: długość podstawy czaszki $(B P)$, szerokość międzyoczodołową (EcEct), szerokość trzewioczaszki $(\mathrm{SmSm})$, wysokość trzewioczaszki (StN) i wysokość mózgowioczaszki $(S p h B r)-$ Ryc. 1. Wyliczono trzy wskaźniki kraniometryczne:

$$
x_{1}=\frac{E c t E c t \times 100}{B P} ; x_{2}=\frac{S t i N \times 100}{S p i 2 B r} ; x_{3}=: \frac{S m S n \times 100}{E c t E c t} \text {. }
$$

$\mathrm{Na}$ wartościach tych wskaźników oparto dwie funkcje dyskryminacyjne, oddzielające czaszki żubrów od czaszek bydła:

dla samców: $z \sigma^{*} \sigma_{(B b-B t)}=0,31 x_{1}+1,10 x_{2}-0,80 x_{3}-70,00$;

dla samic: $\quad z \circ \bigcirc_{(B b-B t)}^{(B b-B t)}=0,63 x_{1}+0,16 x_{2}-0,39 x_{3}-21,00$. 
Współczynniki dyskryminacji, dodatnie dla żubrów i ujemne dla bydła zawiera Tabela 1. Stwierdzono większą różnicę między wspólczynnikami dyskryminacji żubrów i bydła domowego w przypadku samców niż samic.

Powyższym dwom funkcjom podporządkowano następnie wskaźniki kraniometryczne hybrydów $F_{1}, B_{1}, B_{2}$ i $B_{3}$. Stwierdzono, że współczynniki dyskryminacji większości osobników $F_{1}$ (Tabela 1) wykazują ujemne wartości, co świadczy o większym ich podobieństwie do bydła niż do żubrów. W pokoleniach wstecznych powstałych przez kojarzenie samic hybrydów z bykami bydła domowego współczynniki dyskryminacji stają się bardziej ujemne, co jest dowodem dalszego zanikania cech żubrzych w ich czaszkach. U samców hybrydów wszystkich pokolęn razem wziętych istnieje wysoka korelacja między regresem cech żubra w czaszce a pokrewieństwem do żubra (Ryc. 2). Nie stwierdza się podobnej zależności u samic hybrydów.

Czaszki samców hybrydów są jedynie podobne do czaszek samców bydła w mniejszym lub większym stopniu, natomiast nie są pod względem kształtu identyczne $\mathrm{z}$ nimi. U samic hybrydów można wyróżnić czaszki podobne bądź do czaszek żubra bądź bydła, lub też czaszki identyczne pod tym względem $\mathrm{z}$ czaszkami samic bydla domowego.

Przypuszcza się, że prawidłowy przebieg dziedziczenia cech ilościowych czaszki $\mathrm{u}$ osobników pokolenia $\mathrm{F}_{1}$ komplikuje zjawisko heterozji obserwowanej $\mathrm{w}$ tym pokoleniu.

Taksonomia dendrytowa (Ryc. 4 i 5) oparta na wskaźnikach kraniometrycznych ukazuje bogatą różnorodność ksztaltów czaszek hybrydów oraz określa ich podobieństwo do czaszek żubrów i bydła. Samice żubrów z Pszczyny znalazly się nie w zbiorze A, skupiającym wszystkie pozostałe żubry, lecz w zbiorze C, najbardziej niejednorodnym. Przypuszcza się, że nieco inny kształt czaszek tych samic w porównaniu $\mathrm{z}$ innymi żubrami ma związek $\mathrm{z}$ wysokim stopniem inbredu $\mathrm{w}$ linii pszczyńskiej. 